\title{
Perceptions on climate change and adaptation strategies among sweet potato farming households in Kwara State, Northcentral Nigeria
}

\author{
A. Falola ${ }^{1, *}$ and B. A. Achem ${ }^{2}$ \\ ${ }^{1}$ Department of Agricultural Economics and Farm Management, University of Ilorin, P. M. B. 1515, Ilorin, \\ Kwara State, Nigeria \\ ${ }^{2}$ National Centre for Agricultural Mechanization, Ilorin, Kwara State, Nigeria
}

Received: 12/12/2016; Accepted: 30/07/2017

\begin{abstract}
Sweet potato is a food security crop with ease of production and ability to produce relatively good yields even on marginal soils. Despite these potentials, its yields have drastically reduced in recent years relative to what it used to be in the 60's and 90 's. This is not unconnected with climate change, among other factors. This study therefore examines the perceptions of sweet potato farming households on climate change, the strategies employed and factors influencing their adaptation to its effects. Data were collected from 170 sweet potato farming households in Kwara State, Nigeria and analyzed with descriptive statistics, index ranking and logistic regression. Results showed that most of the farmers were aware of climate change and use different strategies to combat its deleterious effects. Factors that positively influence the farmers' adaptation status were educational status, farming experience, farm size and access to agricultural extension services while age had a negative influence on their adaptation status (at $\mathrm{p}<0.05)$. Therefore, policies that will promote literacy and access to extension services among farming households and also encourage young people to practise sweet potato farming should be put in place.
\end{abstract}

Keywords: sweet potato, climate change, effects, adaptation strategies, factors.

\section{INTRODUCTION}

Sweet potato is one of the important food crops globally. Nigeria is the second largest producer of the crop with an annual yield of 3.45 tonnes per hectare [Food and Agricultural Organization (FAO), 2016] after China. In Nigeria, production of sweet potato is concentrated in the northern, semiarid agroecological zone of the country. Sweet potato is a crop with high agronomic potential, ease of production and ability to produce relatively good yields even on marginal soils. Despite these desirable attributes, most sweet potato farmers $(91 \%)$ are smallholders who practise mixed cropping with sweet potato as a minor (secondary) crop (Egeonu and Akoroda, 2010; Bergh et al., 2012).

A critical look at reports by FAO (2016) on sweet potato production in Nigeria shows that though area harvested has increased by more than $4,335 \%$ since 1990, the average yield in 2014 was only $2.8 \mathrm{MT} \mathrm{ha}^{-1}$, down from 5.1MT $\mathrm{ha}^{-1}$ in 1990 and the $1960 \mathrm{~s}$, when yield was once as high as $12.4 \mathrm{MT} \mathrm{ha}^{-1}$. This is not unconnected with climate change, which is currently a topical issue of concern globally, among other factors.

Climate change can be identified, for instance by using statistical tests, by changes in the mean and/or the variability of its properties, and that persists for an extended period typically decades or longer [Intergovernmental Panel on Climate Change (IPCC), 2007]. It includes shifts in the frequency and magnitude of sporadic weather events as well as the slow continuous rise in global mean surface temperature. It also, according to Wiggins and Wiggins (2006), includes any or all of the following among others, unpredictable rainfall, rising temperatures and drought, increased likelihoods of hazards such as floods, landslides and severe cycloids which result in hurricanes and typhoons.

Climate change is gradually attaining a catastrophic dimension given the associated impacts in the various key socio-economic sectors in recent time. One of these sectors is agriculture, specifically the crop sector, which appears to be most susceptible to this phenomenon. Climate affects various aspects of plant growth and development. In fact, it has been predicted that climate change is likely to reduce yields and/or damage crops in the $21 \mathrm{st}$ century (IPCC, 2001). This situation calls for a 
serious concern, as the crop sector in most developing countries countributes immensely to the food security of the poor people (Agwu et al., 2012; Parry et al., 2009). Therefore, adaptation remains the only option for most societies to cope with the projected impacts over the next 100 years.

IPCC (2007) defined adaptation to climate change as an adjustment in natural or human systems in response to actual or expected climatic stimuli or their effects, which moderates harm or exploits beneficial opportunities. It also refers to all adjustments in behaviour or economic structure that reduce the vulnerability of society to changes in the climate system including its current variability and extreme events as well as longer-term climate change. Obayelu et al. (2014) noted that the goal of adaptation to climate change is neither to prevent its negative impacts nor merely clean up after its adverse effects. Rather, it is a long-term resilience, to create the conditions in which the society is largely able to absorb the impacts, such that any residual impact beyond the coping capacity of the society remains within a socially defined acceptable limit of risks. They also noted that adaptation to climate change necessitates that farmers first notice the change, and then identify useful adaptations and implement them.

In order to develop effective and sustainable policies on improving sweet potato production, a sound scientific knowledge of the present adaptation strategies used by the farming households is necessary. Therefore, this study was carried out to analyze the perceptions of climate change on the part of sweet potato farming households in Kwara State, northcentral Nigeria, review their strategies for adapting to this change and determine factors which explain why farmers may or may not adapt to its effects.

\section{MATERIALS AND METHODS}

The study was carried out in two Local Government Areas (LGAs) of Kwara State, Nigeria. Kwara state is geographically located between latitude $7^{0} 20^{\prime}$ and $11^{\circ} 05^{\prime}$ north of the equator longitude $2^{0} 5^{\prime}$ and $6^{0} 45^{\prime}$ East of the prime meridian (Ogunlade et al., 2009). The state has a total land mass of 32,500 square kilometers out of which $75.3 \%$ is cultivable (National Population Commission, 2010).

Kwara State is composed of 16 LGAs, which are formed on the basis of geo-political distributions.
Two of the LGAs, namely; Offa and Oyun, were used for the study, as they both account for $80 \%$ of the output of sweet potato in the state (Kwara State, 2011). Offa LGA is located on latitude 8 N13' East of the Greenwich Meridian and is about $56 \mathrm{~km}$ from Ilorin, the state capital. The LGA is about $600 \mathrm{~m}$ about the sea level and covers about $14,922 \mathrm{~km}^{2}$. Oyun LGA, on the other hand, is located on latitude $8^{\circ} 7^{\prime} 0^{\prime \prime}$ North and longitude $4^{\circ} 42^{\prime} 0^{\prime \prime}$ East in the southern eastern part of the state and is headquartered in Ilemona and has an area of $476 \mathrm{~km}^{2}$. Both LGAs receive rainfall from the south-westerly air masses, which invade the country from the tropical Atlantic. The moist air stream is overhead by the Northeast trade wind which originated from above the Sahara and therefore bring dry and dust laden wind in the dry season which occurs from October - March.

The population of the study area is made up of the Yoruba and other ethnic groups. A humid climate prevails over the area and it has two distinct seasons; the rainy and dry seasons. The rainy season lasts between April and October and the dry season between November and March. The rainfall ranges between $50.8 \mathrm{~mm}$ during the driest months to $2,413.3 \mathrm{~mm}$ in the wettest period. The mean annual rainfall is about 1,500 $\mathrm{mm}$. The minimum average monthly temperature ranges between $21.1^{\circ} \mathrm{C}$ and $25.0^{\circ} \mathrm{C}$ while maximum average monthly temperature ranges from $30^{\circ} \mathrm{C}$ to $35^{\circ} \mathrm{C}$.

The target population for this study was sweet potato farming households in the study area. A three-stage sampling technique was used for the study. The first stage involved a purposive selection of Offa and Oyun LGAs based on the preponderance of sweet potato production in the two LGAs. The second stage involved random selection of twelve farming communities from Offa LGA and four communities from Oyun, based on the proportion of communities in the LGAs. This was followed by a random/proportional selection of farming households across the selected communities based on the number of sweet potato farming households in each community. A total of 170 farming households were interviewed using structured questionnaires. Focus group discussions (FGDs) and face-to-face interviews were also conducted with relevant stakeholders in the communities selected. These were to double-check the data collected from the 
individual farming households. The participants included community leaders, men, women, youth and children. The discussions focused on perceptions on climate changes, possible effects on sweet potato production, adaptation practices currently being applied and barriers to their adaptation strategies.

Analysis of the data obtained was carried out with the use of descriptive statistics, index ranking and logistic regression. The descriptive statistics such as mean, mode, percentages and frequency distribution were used to describe the relevant socio-economic characteristics of the farmers and to assess the perception of the farming households about climate change. Index ranking was used to (i) examine the relevant indicators of climate change in the study area; such as violent winds, delay in onset of rains, early end of the rainy season, flunctuations in the rainfall pattern, increase in daytime temperature and drought (ii) determine the effects of climate change as perceived by the farmers; and (iii) identify the adaptation strategies used by the farmers in mitigating the effects of climate change in the study area. Responses for components (i) and (ii) were rated by using a four-point scale with the scoring order 3, 2, 1 and 0 as high, moderate, low and 'not at all or of no importance' respectively. A weighted average index (WAI) analysis was then estimated using the formular:

$\mathrm{WAI}=\frac{\sum F_{i} W_{i}}{\sum F_{i}}=\frac{W I}{\sum F_{i}}$

where: $F=$ frequency; $W=$ weight of each scale; $i=$ weight; $W I=$ weighted index (Adesoji and Famuyiwa, 2010; Devkota et al., 2014; Uddin et al., 2014; Ndamani and Watanabe, 2016). Component (iii) was rated based on the frequency of the farmers who responded to the multiple-response questions on the different adaptation strategies they used. The questions include whether the respondents changed planting and harvesting dates, switched to other sources of income, altered the time of ploughing or sprayed their crop in response to climate change. Others include use of tolerant varieties, move to different sites, diversify their crops or use water/soil conservation techniques.

The logistic regression model was used to determine factors influencing adaptation to climate change by the sweet potato farmers in the study area. The dependent variable in the model was whether a farmer has adapted or not adapted any adaptation practice to climate change. Thus, adaptation was treated as a dependent dummy variable, taking a value of 1 if a farming household had adopted at least one of the adaptation methods and 0 if otherwise. The independent variables were gender, age of the household head (in years), educational status (number of successful years of schooling), household size (number), farming experience (in years), access to credit ( 1 if yes and 0 if otherwise), farm size (in hectares) and access to agricultural extension services ( 1 if yes and 0 if otherwise). Previous studies have shown that logit models are the most appropriate econometric models to apply to the evaluation of qualitative dependent variables that have dichotomous groups (i.e. 'adapted' and 'not adapted') while the independent variables are categorical, continuous and dummy (Studenmund, 2006; Uddin et al., 2014; ). These models are commonly and widely used since they guarantee that the estimated probability increases lie within the range of 0 to 1 and display a sigmoid curve conforming to the theory of adoption. This study used the functional form of the logistic regression model, presented by Agresti (1996). In this model, dependent variable becomes the natural logarithm of the odds when a positive choice is made. It is expressed as:

$$
\ln \left\{P_{x} /\left(1-P_{x}\right)\right\}=b_{0}+b_{1} X_{1 i}+b_{2} X_{2 i}+\ldots+b_{k}
$$

$$
X_{k i}
$$

where: $P_{x}=$ probability of adaption; $\left(1-P_{x}\right)=$ probability of non-adaption; $i=$ ith observation in the sample; $b_{1}, b_{2} \ldots b_{k}=$ regression coefficients of the explanatory variables; $X_{1}, X_{2} \ldots \ldots . X_{k}=$ explanatory variables; $b_{0}=$ constant term.

\section{RESULTS AND DISCUSSION}

\section{Socio-economic characteristics of the respondents}

Table 1 shows the socio-economic attributes of the respondents. The majority of the household heads were of the male gender and made up about $79 \%$ of the farming households interviewed. A large proportion (65.3\%) of the farmers were within the age range of $21-50$ years. The modal age group was $41-50$ years while the mean age was 44 years. These results 
suggest that the farmers were still in their active/productive age. It is noteworthy, however, that only about $17 \%$ of the farmers were not older than 30 years, which is the official age limit recognized by the National Youth Service Corps (NYSC) in Nigeria for an individual to be referred to as 'youth'. This might be due to the high level of apathy exhibited by the youths to agriculture and this is in consonance with previous studies on youths' participation in agriculture in Nigeria (Adedoyin, 2005; Adewale et al., 2005; Adekunle et al., 2009; MuhammadLawal et al., 2009; Falola et al., 2013).

The majority (77.1\%) of the respondents were married. About $71 \%$ of the farmers had a household size of between 6-10 persons. Further analysis of the results revealed that the mean household size of the respondents was about seven persons. This likely indicates that sweet potato production is a means of catering for the family in the study area.

Table 1: Socio-economic characteristics of the respondents $(N=170)$.

\begin{tabular}{|c|c|c|c|}
\hline Variable & Category & Frequency & Percentage \\
\hline \multirow[t]{2}{*}{ Sex } & Male & 134 & 78.8 \\
\hline & Female & 36 & 21.2 \\
\hline \multirow[t]{5}{*}{ Age (years) } & $21-30$ & 29 & 17.1 \\
\hline & $31-40$ & 32 & 18.8 \\
\hline & $41-50$ & 50 & 29.4 \\
\hline & $51-60$ & 40 & 23.5 \\
\hline & Above 60 & 19 & 11.2 \\
\hline \multirow[t]{3}{*}{ Marital status } & Single & 27 & 15.9 \\
\hline & Married & 131 & 77.1 \\
\hline & Widowed & 12 & 7.1 \\
\hline \multirow[t]{3}{*}{ Household size } & $1-5$ & 36 & 21.2 \\
\hline & $6-10$ & 121 & 71.2 \\
\hline & $11-15$ & 13 & 7.6 \\
\hline \multirow[t]{4}{*}{ Educational level } & No formal & 107 & 62.9 \\
\hline & Primary & 30 & 17.6 \\
\hline & Secondary & 29 & 17.1 \\
\hline & Tertiary & 4 & 2.4 \\
\hline \multirow{4}{*}{$\begin{array}{l}\text { Farming experience } \\
\text { (years) }\end{array}$} & $1-10$ & 52 & 30.6 \\
\hline & $11-20$ & 72 & 42.4 \\
\hline & $21-30$ & 27 & 15.9 \\
\hline & Above 30 & 19 & 11.2 \\
\hline \multirow[t]{3}{*}{ Farm size (hectares) } & $1.00-5.00$ & 129 & 75.9 \\
\hline & $5.01-9.00$ & 36 & 21.2 \\
\hline & Above 9.00 & 5 & 2.9 \\
\hline \multirow{2}{*}{$\begin{array}{l}\text { Access to extension } \\
\text { services }\end{array}$} & Have access & 68 & 40.0 \\
\hline & No access & 102 & 60.0 \\
\hline \multirow{2}{*}{$\begin{array}{l}\text { Membership of farmers' } \\
\text { organization }\end{array}$} & Member & 119 & 70.0 \\
\hline & Non-member & 51 & 30.0 \\
\hline \multirow[t]{2}{*}{ Access to credit } & Have access & 36 & 21.2 \\
\hline & No access & 134 & 78.8 \\
\hline
\end{tabular}

Distribution of the respondents by their educational level shows that a large number of farmers had no formal education. Only $17 \%$ had secondary education while just about $2 \%$ had tertiary education. This scenario might result from the preference for white collar jobs by welleducated individuals, with negligence to agriculture, especially in developing countries 
like Nigeria (Muhammad-Lawal et al., 2009; Falola et al., 2013).

About $69 \%$ of the respondents had been in sweet potato production for more than 10 years (Table 1). Further analysis of the results revealed that the mean farming experience of the farmers was 14 years. This indicates that sweet potato farming is an age-long venture in the study area. About $76 \%$ of the respondents had a farm size of about 1-5 hectares. A large proportion (70\%) of the respondents were members of one farmer association or the other. However, only $40 \%$ of the respondents had access to extension services. Similarly, only few (21\%) of the respondents had access to credit for farm production activities.

\section{Farmers' Perception about Climate Issues in the Study Area}

Table 2 shows the farmers' perception on climate change. Most $(89.4 \%)$ of the farmers were aware of the concept while only $10.6 \%$ were not. The majority of the farmers (who were aware) perceived climate change as a change in the pattern of rains, seasons, sunshine hours (mean daily sunshine hours perceived to be as low as five hours) and daily temperature. This conforms to IPCC reports (IPCC 2001a, 2001b, 2007 \& 2013) and the current widely accepted view that there is variability in climatic conditions.

Further efforts were made to obtain information on the likely indicators of climate change from those who proved to be aware of the concept. The results of their responses are presented in Table 3. The table shows that the significant indicators of climate change perceived by the farmers, in order of decreasing importance, were: delay in the onset of rains, fluctuations in rainfall pattern, early end to the rainy season, increase in daytime temperatures and violent winds.

Table 2: Respondents' perception about climate change $(\mathrm{N}=170)$.

\begin{tabular}{llll}
\hline Variable & Category & Frequency & Percentage \\
\hline Awareness & Yes & 152 & 89.4 \\
*Variations perceived & No & 18 & 10.6 \\
& Wind & 32 & 21.1 \\
& Pattern of rains & 135 & 88.8 \\
& Pattern of seasons & 126 & 82.9 \\
& Sunshine hours & 121 & 79.6 \\
& Daily temperature & 119 & 78.3 \\
\hline
\end{tabular}

Note: * Only those who were aware were considered and multiple responses allowed

Table 3: Indicators of climate change perceived by respondents $(n=152)$.

\begin{tabular}{lllllll}
\hline Indicators & High (3) & Moderate (2) & Low (1) & WI & WAI & Rank \\
\hline Violent winds & 76 & 45 & 31 & 349 & 2.30 & 5 th \\
Delay in the onset of rains & 140 & 12 & - & 444 & 2.92 & 1 st \\
Early end to the rainy season & 98 & 35 & 19 & 383 & 2.52 & 3rd \\
Fluctuations in rainfall pattern & 108 & 32 & 12 & 400 & 2.63 & 2nd \\
Increase in daytime temperatures & 87 & 40 & 25 & 366 & 2.41 & 4th \\
Drought & 32 & 40 & 80 & 256 & 1.68 & 6th \\
\hline
\end{tabular}

Since most of the respondents reported that there were indeeed indicators of climate change in the study area, further investigations were made to know the effects of the change on their farming activities. Table 4 shows the effects of climate change reported by the respondents. Based on the index ranking, it turns out that the most preponderant effect of climate change on sweet potato in the study area was increased pest and disease attack. This is followed by reduced output, infested sweet potato, late maturity of the crop, crop losses, increased cost of production and reduced farm income, in order of decreasing importance.

Table 4 further shows that there is a logical relationship among the effects observed by the farmers. For instance, increased pest and disease attacks is likely to bring about reduced output. It may also result in infested potato which may 
result in increased cost of production and in turn lead to reduced farm income.

Table 5 shows the distribution of the respondents by their adaptation status and adaptation strategies employed in mitigating the effects of climate change in the study area. The majority (79\%) of the farmers used one adaptation strategy or the other in managing the effects of climate change on their sweet potato production. This represents about $89 \%$ of those who were aware of the concept in the study area. The most commonly used strategies applied by the farmers, in order of decreasing importance, were: changing planting and harvesting dates, alteration of the time of ploughing, the use of varieties tolerant to climate stress, spraying, crop diversification and switching to other sources of income. Some of the farmers engaged in changing farm sites as a measure against effects of climate change while only $5.2 \%$ of them engaged in changing soil and water conservation techniques as a measure against climate change.

These results on the measures applied by the farmers in guarding against the effects of Table 4: Effects of climate change perceived by respondents $(n=152)$ climate change in the study area have some policy implications. For instance, changing planting/harvesting dates and moving to different sites, while serving short-term purpose of reducing impact of climate change, may prove unreliable in the long-run. For instance, the uncertainty of onset of rains leading to planting at different dates may make planning the farming calendar difficult. Similarly, moving to new sites may not be a dependable alternative at present when there is competition of land for farming and other uses due to urbanization and industrialization (Haberl, 2014). Also, that only very small percentage of the farmers adopt water and soil conservation methods in guarding against the effects of climate change poses serious concern on ecosystem sustainability. This is because protecting key ecosystems through management of resources such as soil and water confers resilience to the ecosystems (Baron et al., 2008). If farmers do not give attention to such an important aspect of climate change and its mitigatory measures, finding solutions to the impacts of climate change may be difficult to achieve.

\begin{tabular}{lllllll}
\hline Effects & High (3) & Moderate (2) & Low (1) & WI & WAI & Rank \\
\hline Reduced output & 76 & 56 & 20 & 360 & 2.37 & 2nd \\
Late maturity of sweet potato & 66 & 49 & 37 & 333 & 2.19 & 4 th \\
Pest and disease attack & 83 & 43 & 26 & 361 & 2.38 & 1 st \\
Crop loss & 55 & 67 & 30 & 329 & 2.16 & 5 th \\
Reduced farm income & 70 & 17 & 65 & 309 & 2.03 & 7 th \\
Increased cost of production & 54 & 50 & 48 & 310 & 2.04 & 6 th \\
Infested sweet potato & 76 & 51 & 25 & 355 & 2.34 & 3rd \\
\hline
\end{tabular}

Table 5: Adaptation status and strategies applied by respondents.

\begin{tabular}{|c|c|c|c|c|}
\hline Items & Category & Frequency & Percentage & Rank \\
\hline \multirow[t]{2}{*}{ Adaptation status } & Adapted & 135 & 79.4 & - \\
\hline & Did not adapt & 35 & 20.6 & - \\
\hline \multirow{8}{*}{$\begin{array}{l}\dagger \text { †daptation } \\
\text { employed }\end{array}$} & Changing planting and harvesting dates & 102 & $75.6(60.0)$ & $1 \mathrm{st}$ \\
\hline & Switching to other sources of income & 74 & $55.4(43.5)$ & 6th \\
\hline & Alteration of the time of ploughing & 98 & $72.6(57.6)$ & 2nd \\
\hline & Spraying & 83 & $61.5(48.8)$ & 4th \\
\hline & Use of tolerant varieties & 96 & $71.1(56.5)$ & $3 \mathrm{rd}$ \\
\hline & Moving to different sites & 25 & $18.5(14.7)$ & 7th \\
\hline & Crop diversification & 79 & $58.5(46.5)$ & 5 th \\
\hline & $\begin{array}{l}\text { Change in the use of water and soil } \\
\text { conservation techniques }\end{array}$ & 7 & $5.2(4.1)$ & 8th \\
\hline
\end{tabular}

Note: $\uparrow \mathrm{x}(\mathrm{y}) ; \mathrm{x}=$ Expressed in term of those who adapt; $\mathrm{y}=$ Expressed in term of the sample size.

Table 6 shows the factors that determine farmers' adaptation to climate change in the study area. The chi-square of 138.77 obtained in the study implies that the parameters included in the logistic model are significantly different from zero at the $1 \%$ significant level. Also, the 
likelihood function of the model was significant (Wald $=-20.843866$, with $p<0.003$ ). This shows a strong explanatory power of the model. The results shows that the significant factors influencing adaptation to climate change by the farmers were age of the household head, educational status, farming experience, farm size and access to agricultural extension services (at $\mathrm{p}<0.05$ ). The coefficient of farmer's age was significant and negatively related to the probability of a farmer adapting measures against climate change. This implies that older farmers are less likely to adapt measures to guard against the effects of climate change than their younger counterparts. This could be because young individuals, all things being equal, are more innovative to relevant agricultural practices than their older colleagues (Adekunle et al., 2009; Daudu, 2009; Omotesho et al., 2012). Also, studies have revealed that young farmers have more risk-bearing ability to adapt measures against effects of climate change than the elderly ones (Acquah, 2011; Uddin et al., 2014).

Table 6 further shows that educational status had a positive effect on the likelihood of the farmers to use climate change adaptation strategies. This implies that the probability of adaptation to climate change is greater for those who have higher educational attainment compared to less-educated or illiterate farmers. Other things being equal, well educated farmers have more knowledge, greater ability to understand and respond to anticipated changes, are better able to forecast future scenarios and may have greater access to information and opportunities than others, which might encourage adaptation to climate change. Besides, more educated people are better able to adapt to technologies better than less educated ones (Adeogun et al., 2008). A positive effect of education on adaptation to climate change was similarly reported by Deressa et al. (2009), Obayelu et al. (2014) and Onu et al. (2014) in Ethiopia, Ekiti (Nigeria) and Abuja (Nigeria) respectively. The coefficient of farming experience was positive and significantly related to uptake of adaptation strategies by the farmers. This is logical, as experienced farmers are likely to have developed skills over the years. Thus, they may have more knowledge on climatic conditions, especially as they affect their farming operations. This may have a positively significant impacts on the farmers in increasing the use of various adaption options (Onu et al., 2014). Similarly, Table 6 shows that farm size has a positive influence on the likelihood of adaptation to climate change by the farmers. Access to extension services was also significant and positively influenced adaptation to climate change by the farmers. This implies that the likelihood of farmers who have access to extension services to adapt to climate change is greater than those who do not. This could be as a result of information on climate change, its effects and relevant strategies, which the former group may have over their counterparts. This finding is consistent with Onu et al. (2014), Onyeneke and Madukwe (2010), Deressa et al. (2009) and Yesuf et al., (2008).

Table 6: Factors influencing adaptation to climate change by the respondents.

\begin{tabular}{lllll}
\hline Variable & Coefficient & Standard error & $\mathbf{Z}$ & $\mathbf{P}>|\mathbf{z}|$ \\
\hline Age & $-0.053^{*}$ & 0.026 & -2.01 & 0.044 \\
Educational status & $0.871^{*}$ & 0.353 & 2.47 & 0.014 \\
Gender & 0.003 & 0.457 & 0.01 & 0.996 \\
Farming experience & $.075^{*}$ & 0.032 & 2.33 & 0.019 \\
Household size & -0.003 & 0.027 & -0.11 & 0.912 \\
Farm size & $0.825^{*}$ & 0.415 & 1.99 & 0.049 \\
Access to credit & -0.191 & 0.116 & -1.64 & 0.100 \\
Access to agricultural extension services & $1.360^{*}$ & 0.670 & 2.03 & 0.047 \\
Constant & -41.848 & 15.673 & -2.67 & 0.001 \\
LR chi2(8) $=138.77$ & & & & \\
Prob chi2 $=0.003$ & & & & \\
Pseudo R2 $=0.692$ & & & & \\
Log likelihood $=-20.844$ & & & &
\end{tabular}

\section{CONCLUSIONS}

This study reveals that most of the sweet potato farming households in the study area perceive climate change in various forms. These include: delay in the onset of rains, fluctuations in rainfall pattern, early end to the rainy season, increase in daytime temperatures and violent winds. They 
also perceive that climate change has many effects on their farming activities, most of which have negative implications on their farm production. Notwithstanding, some farmers are not taking any adaptive measure against it. This study also shows that though majority of the farming households use different adaptation strategies to combat the deleterious effects of climate change on the farm operations, only about $5 \%$ of them use soil and water conservation techniques. This study further reveals that the factors that positively determine whether or not the farmers adapt to climate change in the study area are educational status, farming experience, farm size and access to agricultural extension services while the farmer's age negatively influenced it.

Given these findings, it is recommended that government should take necessary measures to enhance awareness on the effects of climate change and adaptation strategies. This could be through radio, televisions, newspapers and bulletins, among others. Agricultural extension service providers could also help in this regard. Raising awareness on climate change among farmers would also have greater impact on mitigating impacts of climate change. Since the study revealed that young farmers are more likely to take up adaptation strategies than their old counterparts, policies that will encourage young people to practise sweet potato farming should be formulated. Also, policy drives should be geared towards promoting involvement of well educated individual in sweet potato farming. Therefore, government and other development agencies should promote and improve literacy programme among farmers. Moreover, agricultural development agencies should ensure that farmers have adequate access to extension services. This could be through employment of more extension workers and provision of enabling environment for them to discharge their duties effectively. Besides, extension service providers should train farmers on sound adaptation strategies to climate change. This should include the use of soil and water conservation techniques, which is still lacking among the sweet potato farmers in the study area.

\section{REFERENCES}

Acquah, H.D., (2011). Farmers' perception and adaptation to climate change effects: A willingness to pay. Journal of Sustainable Development in Africa, 13:150-161.
Adedoyin, S.F., (2005). Youth and children programme in Nigeria. In: Agricultural Extension in Nigeria. Agricultural Extension Society of Nigeria, $251 \mathrm{pp}$.

Adewale, J.G., Oladejo, J.A. and Ogunniyi, L.T., (2005). Economic contribution of farm children to agricultural production in Nigeria: A case study of Ekiti State. Journal of Social Sciences, 10(2): 149-152.

Adekunle, O.A., Adefalu, L.L., Oladipo, F.O., Adisa, R.S., and Fatoye, A.D., (2009). Constraints to youth's involvement in agricultural production in kwara state, Nigeria. Journal of Agricultural Extension, 13(1):102-108.

Adeogun, O.A., Ajana, A.M., Ayinla, O.A., Yarhere, M.T., Adeogun, M.O, (2008). Application of logit model in adoption decision: A study of hybrid Clarias in Lagos State, Nigeria. AmericanEurasian Journal of Agricultural and Environmental Sciences, 4:468-472.

Adesoji, S.A., and Famuyiwa, B.S., (2010). Perception and adaptation to climate change among Fulani cattle rearers in Osun State, Nigeria. Proceedings of 15th Annual Conference of Agricultural Society of Nigeria, Pp. 59- 67.

Agwu, N.M., Nwachukwu, I.N., and Anyanwu, C.I., (2012). Climate variability: Relative effect on Nigeria's cassava production capacity. Proceedings of 2012 Annual Conference of the Nigerian Association of Agricultural Economists $(N A A E)$. E. D. Idowu, A. B. Ayanwale, A. S. Bamire and A. O. Adejobi (eds), 516-519. Published by National Association of Agricultural Economists (NAAE).

Baron, J.S., Julius, S.H., West, J.M., Joyce, L.A., Blate, G., Peterson, C.H., Palmer, M., Keller, B.D., Kareiva, P., Scott J.M. and Griffith, B., (2008). Some Guidelines for Helping Natural Resources Adapt to Climate Change. http://www.fs.fed.us/psw/cirmount/publications/p df/IHDP2008_Baron_etal.pdf, (Retrieved 10th February 2016).

Bergh, K., Orozco, P., Gugerty, M.K., and Anderson, C.L., (2012). Sweet potato value chain: Nigeria. Evans School policy Analysis nand Research (EPAR) Brief $\quad$ No. 220. http://evans.uw.edu/sites/default/files/public/EPA R_UW_Request220_Nigeria\%20SP\%20Value\%2 oChain\%20Final.pdf, (Retrieved on 21st July, 2016).

Daudu, S., Okwoche, V.A., Adegboye, O.G., (2009). Role of youths in agricultural development in Makurdi Local Government Area of Benue State. Journal of Agricultural Extension, 13(2):107112.

Deressa, T.T., Hassan, R.M., Ringler, C., Alemu, T., and Yesuf, M. (2009). Determinants of Farmers' choice of adaptation methods to climate change in the Nile Basin of Ethiopia. Global Environmental Change 19:248-255. 
Devkota, R.P.; Cockfield, G.; Maraseni, T.N. (2014). Perceived community-based flood adaptation strategies under climate change in Nepal. International Journal of Global Warming, 6:113124.

Egeonu, I.N., and Akoroda, M.O., (2010). Sweetpotato characterization in Nigeria. A paper presented at Annual Breeders' Meeting in Uganda.

http://www.sweetpotatoknowledge.org/wpcontent/uploads/2016/02/pres20-sp-

characterization-in-nigeria-egeonu-20100625.pdf (Retrieved 21st July, 2016).

Intergovernmental Panel on Climate Change (IPCC) (2001a). Climate change: Impacts, adaptation, and vulnerability. Contribution of Working Group II to the Third Assessment Report of the Intergovernmental Panel on Climate Change; Cambridge University Press: Cambridge, UK, 2001.

Intergovernmental Panel on Climate Change (IPCC) (2001b). Climate Change; Special Report on the regional impacts of climate change: An assessment of vulnerability; Cambridge University Press: Cambridge, UK, 2001.

Intergovernmental Panel on Climate Change (IPCC) (2007). Climate change: Impacts, adaptation and vulnerability: An assessment report of the Intergovernmental Panel on Climate Change; Cambridge University Press: Cambridge, UK, 2007.

Intergovernmental Panel on Climate Change (IPCC) (2013). Climate change: The physical science basis. Contribution of Working Group I to the Fifth Assessment Report of the Intergovernmental Panel on Climate Change; Cambridge University Press: Cambridge, UK, 2013.

Falola, A., Ayinde, O.E., and Ojehomon, V.E.T., (2013). Economic analysis of rice production among the youths in Kwara State, Nigeria. Albanian Journal of Agricultural Sciences, 12(3):503-510.

Food and Agricultural Organization (2016). Food and agricultural commodities production / Countries by commodity. http://faostat3.fao.org/browse/rankings/countries _by_commodity/E, (Retrieved 21st July, 2016).

Haberl, H., (2014). Competition for land: A sociometabolic perspective. Ecological Economics, 119:424-431.

Muhammad-Lawal, A., Omotesho, O.A., and Falola, A., (2009). Technical efficiency of youth participation in agriculture: A case study of the Youth-in-Agriculture Programme in Ondo State, Southwestern Nigeria. Nigerian Journal of Agriculture, Food and Environment, 5(1):20 - 26.
Ndamani, F., and Watanabe, T., (2016). Determinants of farmers' adaptation to climate change: A micro level analysis in Ghana. Scientia Agricola, 73(3):201-208.

National Population Commission (2010). Population and housing census of the federal republic of Nigeria 2009. Priority table. National Population Commission, Abuja, Nigeria; 2009.

Obayelu, O.A., Adepoju, A.O., Idowu, T., (2014). Factors influencing farmers' choices of adaptation to climate change in Ekiti State, Nigeria. Journal of Agriculture and Environment for International Development, 108(1):3-16.

Ogunlade, I., Oladele, O.I, and Babatunde, A.O., (2009). Farmers' attitude to beneficiary funding of extension services in Kwara State, Nigeria. Journal of Human Ecology, 26(3): 215-220.

Omotesho, O.A., Falola, A., Agbonpolor, G., (2012). Analysis of sweet potato production in Offa and Oyun Local Government Areas of Kwara State, Nigeria. Benin International Journal of Agricultural Economics and Extension Services, 2(1):67-75.

Onu, A.D., Tologbonse, E.B., Adeniji, O.B., and Ejechi, M.E., (2014). Analyses of determinants of adaptation to climate change among arable crop farmers in the Federal Capital Territory, Abuja. Nigerian Agricultural Journal, 45(1):54-64.

Onyeneke, R.U., and Madukwe, D.K., (2010). Adaptation measures by crop farmers in the southeast rainforest zone of Nigeria to climate change. Science World Journal, 5(1):32-34.

Parry, M.L., Rosenzweig, C., Igleisias, A., Livermore, M., and Fischer, C., (2009). Effects of climate change on global food production under SRES emissions and socio-economic scenarios. Global Environmental Change, 14:53-67.

Studenmund, A. H. (2006). Using Econometrics: A Practical Guide, 5th ed.; Pearson-Addison Wesley: New York, NY, USA.

Uddin, M.N., Bokelmann, W. and Entsminger, J.S. (2014). Factors affecting farmers' adaptation strategies to environmental degradation and climate change effects: A farm level study in Bangladesh. Climate, 2:223-241.

Wiggins, S. and Wiggins, T., (2006). Climate change and environmental degradation: Risks and adaptation assessment. Teddington, U. K. tear fund.

Yesuf, M., Di Falco, S., Deressa, T., Ringler, C., and Kohlin, G., (2008). The impact of climate change and adaptation on food production in lowincome countries evidence from the Nile Basin, Ethiopia. Environment and Production Technology Division, IFPRI Discussion Paper 00828, IFPRI Washington DC, USA. 